\title{
Size-fractionated uptake of nitrogenous nutrients and carbon by phytoplankton in the North Sea during summer 1994
}

\author{
Roel Riegman*, Anna A. M. Noordeloos \\ Netherlands Institute for Sea Research (NIOZ), PO Box 59, 1790 AB Den Burg, The Netherlands
}

\begin{abstract}
The growth of 2 different algal size classes was studied in July/August 1994 along a transect from the Dogger Bank to the Shetland Islands in the thermally stratified part of the North Sea. Size-differential growth rates were estimated on the basis of independent measurements of carbon and nitrogen uptake. In general, the major nutrients were low in the upper mixed layer At $10 \mathrm{~m}$ depth, average values for phosphate, ammonium, urea, and nitrate were $0.047 \pm 0.019(\mathrm{n}=32), 0.17 \pm 0.05$ $(n=27), 0.15 \pm 0.09(n=26)$, and $0.16 \pm 0.13(n=27) \mu M$, respectively. Nitrate, urea, and ammonium uptake by the total plankton community were 9,31 and $60 \%$ of the total nitrogen uptake, respectively. The $<5 \mu \mathrm{m}$ fraction showed a comparable speciation of nitrate, urea and ammonium uptake being 8,32 and $60 \%$, respectively. The average chlorophyll a (chl a) concentration was $0.68 \pm 0.47 \mu \mathrm{g} \mathrm{l}^{-1}(\mathrm{n}=34)$, and $71 \%$ of the total chl a was in the $<5 \mu \mathrm{m}$ fraction. The average specific growth rate of $<5 \mu \mathrm{m}$ phytoplankton $\left(0.39 \pm 0.17 \mathrm{~d}^{-1} ; \mathrm{n}=19\right)$ was not significantly different $(0.25>\mathrm{p}>0.1)$ from the specific growth rate of the $>5 \mu \mathrm{m}$ fraction $\left(0.43 \pm 0.12 \mathrm{~d}^{-1} ; \mathrm{n}=15\right)$. At $40 \mathrm{~m}$ depth, i.e. just below the chl a maximum near the thermocline, major nutrients were present at non-limiting concentrations and photosynthetic active radiation (PAR) ranged between 2 and $5 \%$ of the surface PAR. Average values for phosphate, ammonium, urea, and nitrate were $0.40 \pm 0.13(\mathrm{n}=32), 1.40 \pm 0.90(\mathrm{n}=34), 0.15 \pm 0.06(\mathrm{n}=34)$, and $2.61 \pm$ $1.79(\mathrm{n}=34) \mu \mathrm{M}$, respectively. At $40 \mathrm{~m}$ depth, more nitrate was consumed than at $10 \mathrm{~m}$ depth: nitrate, urea, and ammonium uptake by the total community were 17,16 and $67 \%$ of the total nitrogen uptake, respectively. The $<5 \mu \mathrm{m}$ fraction showed a lower preference for nitrate with nitrate, urea and ammonium uptake being 12,14 and $74 \%$ of the total nitrogen uptake by this size fraction, respectively. The average chl a at $40 \mathrm{~m}$ was $0.63 \pm 0.42(\mathrm{n}=34)$, and also at this depth $71 \%$ of the total chl $a$ was in the $<5 \mu \mathrm{m}$ fraction. The average specific growth rate of phytoplankton was lower at greater depth: $0.17 \pm$ $0.09 \mathrm{~d}^{-1}(\mathrm{n}=15)$ for the $<5 \mu \mathrm{m}$ fraction. The specific growth rate of the phytoplankton $>5 \mu \mathrm{m}$ was $0.10 \pm 0.06 \mathrm{~d}^{-1}(\mathrm{n}=15)$, which was significantly lower than the value for the smaller size fraction $(p<0.025)$. Net primary production showed large variation amongst the stations with average values for the $<5 \mu \mathrm{m}$ fraction and the total community of $0.37 \pm 0.19 \mathrm{~g} \mathrm{C} \mathrm{m}^{-2} \mathrm{~d}^{-1}(\mathrm{n}=20)$ and $0.50 \pm 0.26 \mathrm{~g} \mathrm{C}$ $\mathrm{m}^{-2} \mathrm{~d}^{-1}(\mathrm{n}=20)$, respectively. In combination with the companion paper it is concluded that sizepartitioning of algal growth rate appears to depend on the character of the growth rate limiting factor. Smaller algae showed faster growth than larger ones in light-controlled environments, regardless of the nitrogen source predominantly used. In the nutrient-controlled surface layers, no size-partitioning of algal growth rate was present when ammonium was the major nitrogen source. At some stations, where nitrogen limitation co-occurred with enhanced nitrate consumption, larger algae did grow faster than smaller ones. However, the algal biomass in different size classes was not related to the estimated growth rates of these different categories. Apparently, larger algae do not dominate during summer in the surface layers of the stratified central North Sea, since mesozooplankton densities are high compared to spring and vertical mixing in the photic zone is low. At the lower part of the photic zone, the larger algae do not dominate since they grow much slower than the smaller species due to lightlimitation
\end{abstract}

KEY WORDS: Phytoplankton growth - Size fractionation - Nitrogen uptake Carbon uptake North Sea 


\section{INTRODUCTION}

In the companion study, we described size-fractionated nitrogen uptake and phytoplankton growth along a transect from the Dogger Bank (North Sea) to the Shetland Islands during spring, when typically lightcontrolled phytoplankton growth occurred (Riegman et al. 1998, in this issue). It was found that, although the spring bloom mainly consisted of larger species, smaller algae $(<5 \mu \mathrm{m})$ grew faster than the larger ones. These findings consolidated the concept of size-differential control of phytoplankton communities (Thingstad \& Sakshaug 1990) under typical spring bloom conditions which originally was demonstrated in a coastal area (Riegman et al. 1993). During summer, the northern part of the North Sea is thermally stratified, exhibiting a major nutrient-depleted surface layer (Woodward \& Owens 1990), a chlorophyll a (chl a) maximum near the thermocline at 30 to $35 \mathrm{~m}$ depth (Riegman et al, 1990a), and deeper water layers where low irradiances and temperature prevail and inorganic nutrients are still available. An inflow of nutrient-rich ocean water occurs near the Shetland Islands which occasionally may trigger Emiliania huxleyi or cyanobacterial blooms (Van der Wal et al. 1995, Timmermans et al. 1998) in the surface layers. In the central North Sea, the major nutrient sources are internal recycling and entrainment from below the thermocline. Primary production is about 0.8 to $1.2 \mathrm{~g} \mathrm{C} \mathrm{m}^{-2} \mathrm{~d}^{-1}$ at chl a levels of $0.4 \mathrm{\mu g} \mathrm{l}^{-1}$ (Gieskes \& Kraay 1984, Riegman \& Colijn 1991). Over the northern slope of the Dogger Bank, where the water column is 30 to $40 \mathrm{~m}$, enhanced chl a near the bottom has been reported (Riegman et al. 1990a, Nielsen et al. 1993). The locally associated enhanced primary production has been ascribed to interaction between wind and tidal mixing at this particular site, promoting the net upwards transport of major nutrients (Riegman et al. 1990a). Generally, phytoplankton is dominated by species $<5 \mu \mathrm{m}$ during summer. Especially in the most oligotrophic central North Sea they contribute up to $75 \%$ of the primary production in the surface layers (Owens et al. 1990). Either nitrogen or phosphorus has been found to limit the growth rate of algae (Riegman et al. 1990b) in the central North Sea, whereas near the Shetlands a potential iron limitation of nitrate reduction has been reported (Timmermans et al. 1998). The dominance of smaller algae in stratified, nutrient-controlled waters is usually explained by their reduced losses by sedimentation compared to larger species (Margalef 1978) and the ability of smaller species to compete for nutrients as a consequence of their relatively higher surface to volume ratio (Blasco et al. 1982, Grover 1989). It can be argued that species with a high surface to volume ratio are good competitors under steady state conditions, but under transient state conditions the storage capacity for the growth rate limiting nutrient becomes an additional factor that determines the competitive ability of the species. It has been demonstrated that, due to their higher storage capacity, larger diatoms were better competitors for nitrate (under fluctuating supply rates and nitrogen limiting growth conditions) than smaller diatoms (Stolte et al. 1994, Stolte \& Riegman 1995). On the other hand, when ammonium (which could not be stored in the vacuole in large quantities) was supplied instead of nitrate, there was no sizedifferential growth observed when the nutrient supply was fluctuating. In mixed algal species cultures, it was observed that smaller species usually competed better for nutrients than larger ones (Riegman et al. 1996). Extrapolation of these laboratory results is hampered by the lack of quantitative information on the variability of nutrient concentrations that individual algal cells experience in their natural environment.

Field observations on the specific growth rate of algae in different size classes within the same sample in nutrient-controlled environments are rare. In some reports, small algae were growing faster and were more heavily grazed than the larger species (Strom \& Welschmeyer 1991, McManus \& Ederington-Cantrell 1992, Riegman et al. 1993, Kamiyama 1994, Landry et al. 1995. Gallegos et al. 1996), whereas in other studies (Verity 1986, Paranjape 1990) no indications were found for size-differential growth and grazing rates. Also, some studies illustrate the tendency of small and large cells to prefer reduced and oxidized forms of nitrogen, respectively (Probyn 1985, Probyn \& Painting 1985, Harrison \& Wood 1988, Probyn et al. 1990), whereas other studies do not (Chisholm 1992, Dauchez et al. 1996). Estimated growth rates of natural phytoplankton assemblages (Riegman et al. 1993, Kristiansen et al. 1994) are usually lower than the maximum growth rate potentially achievable at the in situ temperature (Eppley 1972), indicating that natural populations usually are limited in their growth rate by light and/or nutrient availability.

Primary production in the upper layer of stratified and nutrient-controlled waters is usually mainly dependent on the internal regeneration of nitrogen, indicated by the uptake of ammonium and urea (sensu Dugdale \& Goering 1967), and the import of nitrogen from below the photic zone, where nitrate uptake as percentage of the total nitrogen uptake ( $f$-ratio; Eppley \& Peterson 1979) is considered as indicative for the ratio between new and regenerative production. $f$-ratios have been reported for the central North Sea during summer stratification ranging between 12 and $55 \%$ in the surface layers (Owens et al. 1990). However, these data were established without the consideration of urea uptake, which may have resulted in a 
$40 \%$ overestimation of new production (Wafar et al. 1995).

Here we describe a study along a transect from the Dogger Bank area to the Shetland Islands (North Sea) during summer on size-fractionated growth rate of phytoplankton, estimated from ${ }^{14} \mathrm{C}$-bicarbonate and ${ }^{15} \mathrm{~N}$-ammonium, urea, and nitrate uptake. In an earlier study during spring, it was found that, in the absence of stratification, new production was higher than regenerative production and algae $<5 \mu \mathrm{m}$ grew faster than larger ones in this typically light-controlled environment (Riegman et al. 1998). During the summer cruise, we investigated size-fractionated algal growth rates and the uptake of different nitrogen sources in the same area, when stratification and major nutrient availability controlled the phytoplankton communities. During summer, nitrogen is the main controlling nutrient in the upper layer of the photic zone in offshore areas of the North Sea (Riegman et al. 1990b).

\section{MATERIAL AND METHODS}

The cruise track and the location of the stations between the northern slope of the Dogger Bank

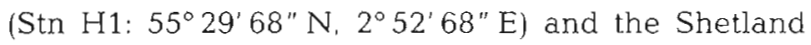
Islands (Station H7: 61.00 $00^{\prime} 24^{\prime \prime} \mathrm{N}, 0^{\circ} 46^{\prime} 19^{\prime \prime} \mathrm{E}$ ) is presented in Riegman et al. (1998). Along the transect there were 7 main stations ( $\mathrm{HO}$ to $\mathrm{H7}$ ). Additionally, there were 6 sub-stations ( $\mathrm{N} 1$ to N6) located in between these main stations, and 16 sub-stations located $32 \mathrm{~km}$ eastwards (E0 to E7) and westwards (W0 to W7) of the main stations. At all stations CTD profiles were obtained to provide information on temperature, light attenuation, turbidity and fluorescence between 25 July and 11 August 1994. At various depths, samples were taken with NOEX bottles for carbon fixation and chl $a(10$ and $40 \mathrm{~m})$, and nutrients (at 12 different depths).

Incident solar irradiance was measured for $2 \mathrm{wk}$ on board ship, using a Kipp Solarimeter. The photosynthetically available radiation (PAR) was calculated from the average daily irradiance assuming PAR to be $45 \%$ of the total irradiance and expressed as $\mathrm{J} \mathrm{m}^{-2} \mathrm{~s}^{-1}$ (Lüning 1981). Light reflection at the sea surface was assumed to be $3 \%$ of the total irradiance (Vermij 1987). The underwater attenuation coefficient $\left(K_{\mathrm{d}}, \mathrm{m}^{-1}\right)$ was calculated from underwater quantum measurements (PAR sensor, Biospherical) and fitted according to the Lambert-Beer law.

$\mathrm{NH}_{4}, \mathrm{NO}_{3}$, urea, and phosphate were measured with a TRAA autoanalyser system. $\mathrm{NH}_{4}$ was detected immediately after sampling as indo-phenolblue-complex (pH 10.5) at $630 \mathrm{~nm}$ (Helder \& de Vries 1979); $\mathrm{NO}_{3}$ was reduced in a copper cadmium coil to nitrite (using imidazole as a buffer) and then measured as nitrite $\mathrm{NO}_{2}$ was detected after diazotation with sulphanilamide and $\mathrm{N}$-(1-naphtyl)-ethylene diammonium dichloride as the reddish purple dye complex at $540 \mathrm{~nm}$ (Grasshoff 1967). Urea was determined within 1 mo after storage at $-30^{\circ} \mathrm{C}$ and measured at $520 \mathrm{~nm}$ after condensation with diacetylmonoxime to form a pink coloured complex using thiosemicarbazide to intensify and ferrichloride to stabilize the colour. Phosphate was determined according to Strickland \& Parsons (1972).

Samples for chl a analysis were collected by filtration (Whatman GF/F for unfractionated phytoplankton and by polycarbonate filters [Poretics, $5 \mu \mathrm{m}$ ] for the $>5 \mu \mathrm{m}$. fraction) and analyzed on board fluorometrically according to the method of Holm-Hansen et al. (1965).

Carbon fixation was estimated using the ${ }^{14} \mathrm{C}$ technique (Riegman \& Colijn 1991).

Water samples were taken from 2 different depths (10 $\mathrm{m}$ and $40 \mathrm{~m}$ below the surface) and subdivided in $50 \mathrm{ml}$ subsamples. Prior to incubation $5 \mu \mathrm{Ci}$ $\mathrm{NaH}^{14} \mathrm{CO}_{3}$ (Amersham) was added to subsamples in a thermostated irradiance gradient incubator at ambient temperatures. The incubator was illuminated with an Osram metallogen HMI $1200 \mathrm{~W}$ lamp, the spectrum of which closely resembles that of natural sunlight (Colijn 1983). Different irradiances were achieved using neutral density filters (Lee, Andover, UK). The side walls of the incubation vessels (tissue culture bottles; Greiner, Solingen, Germanyl were covered with black tape to ensure illumination exclusively from the front. It was concluded from previous tests that this precaution improved the reproducibility of P/I (photosynthesis/irradiance) measurements. Irradiances were measured prior to every incubation using a Licor LI-192 SA underwater Quantum sensor. Calculation of the average irradiance of each vessel was based on in- and outcoming irradiance which was measured for each incubation series. For the establishment of $1 \mathrm{P} / \mathrm{I}$ relationship at least 7 irradiances (ranging from 10 to $3000 \mu \mathrm{E} \mathrm{m}^{-2} \mathrm{~s}^{-1}$ ) were used. After incubation for $2 \mathrm{~h}$, samples were filtered through $5 \mu \mathrm{m}$ pore size Poretics polycarbonate membrane filters and the filtrate across Whatman GF/F filters with a gentle filtration pressure $(-12 \mathrm{kPa}$ relative to atmospheric pressure) to obtain size-fractionated carbon fixation rates. Filters were fumed over conc. $\mathrm{HCl}$ for at least $10 \mathrm{~min}$ and counted in a liquid scintillation counter after addition of $10 \mathrm{ml}$ Instagel If (Packard Canberraj. Total inorganic carbon was determined with a TOC analyzer (model 700; IO Corporation, College Station, TX, USA).

Filter absorption was found to be negligible. Dark values, never exceeding $5 \%$ of the maximum photosynthesis rate, were not subtracted from light values (Mortain-Bertrand et al. 1988). 
P/I curves were fitted according to Platt et al. (1980). Daily carbon fixation profiles were calculated from the average PAR, $K_{d}$, the measured P/I relationship, and corrected for the vertical distribution of phytoplankton as indicated by the fluorescence measurements. This incubator method has been found to deviate by less than $10 \%$ from in situ measurements (Riegman \& Colijn 1991).

Nitrate, ammonium and urea incorporation rates were estimated using ${ }^{15} \mathrm{~N}$. From 10 and $40 \mathrm{~m}$ depth, 11 samples were spiked with either ${ }^{15} \mathrm{NH}_{4}{ }^{+},{ }^{15} \mathrm{NO}_{3}{ }^{-}$or ${ }^{15} \mathrm{~N}$-urea added in trace amounts and incubated in polycarbonate bottles. We enriched the samples with $10 \%$ of the ambient concentration, subject a minimum of $0.1 \mu \mathrm{M}$, to prevent isotope dilution effects during the $2 \mathrm{~h}$ incubation period. We corrected for this enrichment assuming that the nutrient uptake rate is linearly related to its concentration. The bottles were incubated at in situ temperature $\left(9\right.$ to $12^{\circ} \mathrm{C}$ at $40 \mathrm{~m}$ and 13 to $18^{\circ} \mathrm{C}$ at $10 \mathrm{~m}$ depth) and a photon flux density of $80 \mu \mathrm{E} \mathrm{m}^{-2} \mathrm{~s}^{-1}$ corresponding to $10 \mathrm{~m}$ depth and $15 \mu \mathrm{E}$ $\mathrm{m}^{-2} \mathrm{~s}^{-1}$ corresponding to $40 \mathrm{~m}$ depth. After $2 \mathrm{~h}$, the incubation was terminated by filtration of $300 \mathrm{ml} \mathrm{sam}$ ples using maximally $-12 \mathrm{kPa}$. Filtration through a precombusted Whatman GF/F filter was performed to obtain the uptake by the total particulate material. The $<5 \mu \mathrm{m}$ fraction was collected on a precombusted Whatman GF/F filter after filtration through a $5 \mu \mathrm{m}$ pore size polycarbonate filter (Poretics). The filters were stored at $-50^{\circ} \mathrm{C}$ for no longer than 3 mo before analysis. Filters were then dried and acidified twice with $7 \%$ $\mathrm{H}_{2} \mathrm{SO}_{3}$ to remove inorganic carbon. Particulate carbon, nitrogen and $\delta^{15} \mathrm{~N}$ were determined using a Carlo Erba Instruments NA 1500 Series 2 CNS Analyzer on line with a VG Isotech Optima Stable Isotope Mass Spectrometer. ${ }^{15} \mathrm{~N}$ incorporation rates were calculated after Dugdale \& Goering (1967).

The specific growth rate of phytoplankton $\left(\mu_{N}\right)$ based on hourly nitrogen uptake in the light, was calculated by dividing the total inorganic nitrogen uptake rate by chl a and assuming a cellular $\mathrm{N} / \mathrm{chl}$ a ratio of

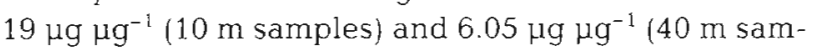
ples). This ratio was calculated from the average total particulate N/total chl a ratio measured at all stations. Application of an average $\mathrm{N} / \mathrm{chl}$ a ratio was chosen since there might be a variable variation in this ratio due to a contribution of non-phytoplankton species to the particulate $\mathrm{N}$ fraction. This could cause wrong estimates at some stations, especially when heterotrophs were much more abundant than algae.

The hourly based specific growth rate was converted to a daily rate by multiplying by $3 / 4$. This irradiance factor was introduced on the assumption that the algae experienced light only for $16 \mathrm{~h}$ of the day, during which time they would take up nitrogen at the same rate as under the experimental conditions. However, nitrogen uptake shows diel variability (Glibert \& Garside 1992). Therefore, it was assumed that, during the $8 \mathrm{~h}$ dark period, the $\mathrm{N}$ uptake rate would be $25 \%$ of the measured uptake rate in the light (Cochlan et al. 1991).

The specific growth rate of algae, based on the measured inorganic carbon fixation rates, was calculated by dividing the daily carbon fixation of the water column by the depth of the photic zone, the chl a content of the photic zone, and assuming a $\mathrm{C} / \mathrm{chl}$ a ratio of 60 (Gieskes \& Kraay 1984). Additionally, this apparent growth rate was multiplied by 0.66 to yield the estimated specific growth rate. This factor was based on the assumption that during the $8 \mathrm{~h}$ dark period no carbon was fixed, and storage products are converted into new cell material with an efficiency in cell synthesis of $33 \%$ in order to maintain the same growth rate in the dark period (Riegman 1985). Primary production over the photic zone was calculated as the product of the specific growth rate (calculated from nitrogen uptake rate; $\mu N$ ), the depth of the photic zone, chl a and a $\mathrm{C} / \mathrm{chl}$ a ratio of 60 for the upper mixed layer and 25 for the lower part of the photic zone around the thermocline. Statistics were performed using Student's t-test.

\section{RESULTS}

According to the CTD profiles, the water column was stratified at all stations along the transect. Near the Dogger Bank, at Stns $\mathrm{H} 1$ to $\mathrm{H} 2$, the thermocline was between 20 and $28 \mathrm{~m}$ depth. At the other stations, the thermocline was located at 30 to $40 \mathrm{~m}$ depth. A detailed hydrographical description of the area is presented elsewhere (Kuipers \& Witte 1998). In general, the major nutrients were low in the upper mixed layer. At $10 \mathrm{~m}$ depth, average values for phosphate, ammonium, urea, and nitrate were $0.047 \pm$ $0.019(\mathrm{n}=32), 0.17 \pm 0.05(\mathrm{n}=27), 0.15 \pm 0.09(\mathrm{n}=$ 26), and $0.16 \pm 0.13(n=27) \mu M$, respectively. In contrast to ammonium and urea, which were low along the entire transect (Table 1), nitrate was enhanced (up to $1.05 \mu \mathrm{M}$ at Stn E7) near the Shetland Islands. At $40 \mathrm{~m}$ depth, i.e. 2 to $6 \mathrm{~m}$ below the fluorescence maximum near the thermocline, PAR was 2 to $5 \%$ of the surface PAR. At these reduced irradiances, the average levels of phosphate, ammonium, urea, and nitrate were higher compared to the $10 \mathrm{~m}$ values: $0.40 \pm 0.13(\mathrm{n}=32), 1.40 \pm 0.90(\mathrm{n}=34), 0.15 \pm 0.06$ ( $n=34)$, and $2.61 \pm 1.79(n=34) \mu M$, respectively. Ammonium at $40 \mathrm{~m}$ varied amongst the stations, urea was below $0.5 \mu \mathrm{M}$, and nitrate was higher than $3 \mu \mathrm{M}$ at all stations in the northern part of the transect (W5 to W7: Table 1). 
Table 1. Dissolved nitrogen concentrations and nitrogen uptake rates $(V)$ at $10 \mathrm{~m}$ and $40 \mathrm{~m}$ depth at the various stations along the transect from the Dogger Bank to the Shetland Islands in August/July 1994

\begin{tabular}{|c|c|c|c|c|c|c|c|c|c|c|c|c|}
\hline $\begin{array}{l}\text { Station } \\
\text { no. }\end{array}$ & $\mathrm{NH}_{4}{ }^{+}$ & $\begin{array}{l}10 \mathrm{~m} \\
\mathrm{NO}_{3}\end{array}$ & Urea & $\mathrm{NH}_{4}{ }^{+}$ & $\begin{array}{l}40 \mathrm{~m} \\
\mathrm{NO}_{3}^{-}\end{array}$ & Urea & $V_{\mathrm{NH}_{4}}{ }^{-}$ & $\begin{array}{l}10 \mathrm{~m} \\
V_{\mathrm{NO}_{3}}\end{array}$ & $\begin{array}{l}V_{\text {urea }} \\
\quad(\mathrm{mg}\end{array}$ & $\begin{array}{c}V_{\mathrm{NH}_{i}} \\
\left.\mathrm{~h}^{-1}\right)\end{array}$ & $\begin{array}{l}40 \mathrm{~m} \\
V_{\mathrm{NO}_{3}}\end{array}$ & $V_{\text {ured }}$ \\
\hline $\mathrm{H} 1$ & 0.14 & 0.11 & 0.20 & & & & 0.089 & 0.015 & 0.105 & & & \\
\hline $\mathrm{H} 1$ & 0.10 & 0.09 & 0.05 & 0.14 & 0.10 & 0.11 & 0.017 & 0.007 & 0.045 & 0.038 & 0.023 & 0.075 \\
\hline E1 & & & & 0.15 & 0.09 & 0.11 & & & & 0.078 & 0.028 & 0.045 \\
\hline W1 & & & & 0.25 & 0.31 & 0.15 & & & & 0.095 & 0.041 & 0.030 \\
\hline N1 & 0.24 & 0.10 & 0.19 & 2.15 & 4.71 & 0.35 & 0.143 & 0.014 & 0.008 & 0.059 & 0.041 & 0.011 \\
\hline $\mathrm{H} 2$ & 0.22 & 0.10 & 0.12 & 2.05 & 0.87 & 0.21 & 0.424 & 0.010 & 0.094 & 0.137 & 0.023 & 0.070 \\
\hline E2 & 0.12 & 0.09 & 0.10 & 1.15 & 1.39 & 0.16 & 0.144 & 0.014 & 0.094 & & & \\
\hline W2 & 0.16 & 0.09 & 0.13 & 1.08 & 2.94 & 0.28 & & & & 0.192 & 0.279 & 0.141 \\
\hline N2 & 0.17 & 0.13 & 0.22 & 0.63 & 0.31 & 0.08 & 0.217 & 0.013 & 0.131 & & & \\
\hline H3 & 0.20 & 0.07 & 0.12 & 0.21 & 0.10 & 0.07 & 0.061 & 0.009 & 0.003 & 0.042 & 0.006 & 0.003 \\
\hline E3 & 0.20 & 0.09 & 0.07 & 0.20 & 3.45 & 0.12 & 0.115 & 0.010 & 0.009 & & & \\
\hline W3 & & & & 1.01 & 2.74 & 0.21 & & & & 0.065 & 0.003 & 0.017 \\
\hline N3 & & & & 2.43 & 2.91 & 0.28 & & & & 0.049 & 0.010 & 0.003 \\
\hline $\mathrm{H} 4$ & 0.14 & 0.08 & 0.10 & 2.68 & 1.78 & 0.13 & 0.089 & 0.013 & 0.023 & & & \\
\hline E4 & & & & 0.74 & 1.67 & 0.09 & & & & 0.040 & 0.006 & 0.003 \\
\hline W4 & 0.20 & 0.08 & 0.22 & 1.72 & 1.50 & 0.26 & 0.256 & 0.037 & 0.197 & & & \\
\hline N4 & 0.22 & 0.12 & 0.25 & 0.67 & 1.36 & 0.10 & 0.250 & 0.030 & 0.258 & & & \\
\hline H5 & 0.16 & 0.09 & 0.05 & 0.36 & 0.33 & 0.08 & 0.287 & 0.026 & 0.056 & 0.047 & 0.004 & 0.006 \\
\hline E5 & 0.13 & 0.07 & 0.07 & 0.55 & .023 & 0.12 & 0.196 & 0.020 & 0.057 & & & \\
\hline W5 & 0.11 & 0.08 & 0.11 & 0.34 & 3.62 & 0.13 & 0.154 & 0.018 & 0.088 & & & \\
\hline N5 & 0.02 & 0.04 & 0.06 & 1.57 & 3.78 & 0.12 & 0.039 & 0.020 & 0.069 & & & \\
\hline H6 & 0.12 & 0.07 & 0.12 & 2.01 & 6.38 & 0.12 & 0.232 & 0.055 & 0.129 & 0.020 & 0.005 & 0.001 \\
\hline E6 & 0.26 & 0.04 & 0.12 & 2.60 & 5.63 & 0.19 & 0.559 & 0.032 & 0.212 & & & \\
\hline W6 & 0.30 & 0.05 & 0.25 & 2.45 & 5.43 & 0.22 & 0.346 & 0.030 & 0.309 & & & \\
\hline N6 & 0.16 & 0.33 & 0.07 & 2.72 & 3.33 & 0.26 & 0.179 & 0.090 & 0.074 & 0.024 & 0.003 & 0.003 \\
\hline $\mathrm{H} 7$ & 0.28 & 0.69 & 0.03 & 2.12 & 6.04 & 0.09 & 0.017 & 0.043 & 0.008 & 0.017 & 0.004 & 0.001 \\
\hline E7 & 0.21 & 1.05 & 0.06 & 2.23 & 6.00 & 0.17 & & & & 0.012 & 0.002 & 0.001 \\
\hline W7 & 0.16 & 0.26 & 0.04 & 2.78 & 4.88 & 0.15 & & & & & & \\
\hline
\end{tabular}

Chl a (Table 2) showed 2 opposite trends at the 2 different depths. In the upper layer, the highest chl a values were found near the Shetland Islands, whereas at $40 \mathrm{~m}$ the highest values were recorded near the northern slope of the Dogger Bank. The average value for total chl $a$ along the entire transect was $0.68 \pm 0.47$ $(\mathrm{n}=34)$ at $10 \mathrm{~m}$ and $0.63 \pm 0.42(\mathrm{n}=34)$ at $40 \mathrm{~m}$. At stations with enhanced chl $a$, the size distribution reflected in the $<5 \mu \mathrm{m}$ fraction and total chl a fraction was similar between most stations (Table 2). At both depths $71 \%$ of the total chl a was in the $<5 \mu \mathrm{m}$ fraction.

The nitrogen uptake rate (Table 1) showed a comparable distribution as $\mathrm{chl}$ a. At $10 \mathrm{~m}$, lower values were found at the oligotrophic stations $\mathrm{H} 1$ to $\mathrm{E} 3$ than at W3 to $E 7$ for ammonium and nitrate uptake. The average total nitrogen uptake rate (i.e. the sum of ammonium, urea, and nitrate uptake) was $0.31 \pm 0.15 \mathrm{mg} \mathrm{N} \mathrm{m}^{-3} \mathrm{~h}^{-1}$ $(\mathrm{n}=24)$ for the total communities, and $0.23 \pm 0.11 \mathrm{mg} \mathrm{N}$ $\mathrm{m}^{-3} \mathrm{~h}^{-1}(\mathrm{n}=22)$ for the fraction $<5 \mu \mathrm{m}$. Lower nitrogen uptake rates were observed at $40 \mathrm{~m}$ depth: the average total nitrogen uptake was $0.12 \pm 0.09 \mathrm{mg} \mathrm{N} \mathrm{m}{ }^{-3} \mathrm{~h}^{-1}$ $(\mathrm{n}=17$ ) for the total communities, and $0.10 \pm 0.08 \mathrm{mg} \mathrm{N}$ $\mathrm{m}^{-3} \mathrm{~h}^{-1}(\mathrm{n}=15)$ for the fraction $<5 \mu \mathrm{m}$. In this deeper layer, the highest activity was near the Dogger Bank (Stns $\mathrm{H} 1$ to W2).
The main inorganic nitrogen component taken up by the plankton was ammonium. The relative contribution of the different inorganic nitrogen substrates to the total nitrogen uptake is presented in Fig. 1.

At $10 \mathrm{~m}$, nitrogen uptake by the total plankton community (Fig. 1b) for nitrate, urea, and ammonium were 9,31 and $60 \%$ of the total nitrogen uptake, respectively (Table 3 ). The $<5 \mu \mathrm{m}$ fraction (Fig. 1a) showed a comparable speciation for nitrate, urea and ammonium uptake, being 8,32 and $60 \%$, respectively. Along the entire transect, the $f$-ratio for nitrate remained low in the surface layer for both size fractions. At $40 \mathrm{~m}$, more nitrate, relative to the reduced nitrogen sources, was used. The nitrogen uptake of the total plankton community (Fig. 1d) for nitrate, urea, and ammonium was 17. 16 and $67 \%$ of the total nitrogen uptake, respectively (Table 3). Especially at the northern slope of the Dogger Bank, the $f$-ratio for nitrate was enhanced in the deeper layer (on the average $23 \%[n=7]$ at Stns H1 to N2). Plankton in the $<5 \mu \mathrm{m}$ fraction showed also a higher relative uptake of nitrate at greater depth (Fig. 1c): at $40 \mathrm{~m}$ nitrate, urea, and ammonium contributed 12,14 and $74 \%$, respectively, to the total $\mathrm{N}$ uptake. At Stns $\mathrm{H} 1$ to $\mathrm{N} 2$, the $f$-ratio for nitrate of the $<5 \mu \mathrm{m}$ fraction $(14 \%, \mathrm{n}=6)$ was lower than the $f$-ratio 
Table 2. Total chl $a$ and chl $a$ of the particle size fraction $<5 \mu \mathrm{m}$ sampled at $10 \mathrm{~m}$ and $40 \mathrm{~m}$ depth, and gross Carbon Fixation Rate (CFR) at the various stations along the transect from the Dogger Bank to the Shetland Islands in August/July 1994

\begin{tabular}{|c|c|c|c|c|c|c|}
\hline \multirow{2}{*}{$\begin{array}{l}\text { Station } \\
\text { no. }\end{array}$} & \multicolumn{2}{|c|}{$10 \mathrm{~m}$} & \multicolumn{2}{|c|}{$40 \mathrm{~m}$} & \multirow[b]{2}{*}{$\begin{array}{c}\text { CFR } \\
<5 \mu \mathrm{m} \\
\text { (g C m }\end{array}$} & \multirow[b]{2}{*}{$\begin{array}{l}\text { CFR } \\
\text { Tota } \\
\left.-2 \mathrm{~d}^{-1}\right)\end{array}$} \\
\hline & $\begin{array}{r}\text { Chl } a \\
<5 \mu \mathrm{m} \\
-\quad(\mu \mathrm{g}\end{array}$ & $\begin{array}{l}\text { Chl a } \\
\text { Total } \\
\left.\left.\right|^{-1}\right\}-\end{array}$ & $\begin{array}{l}\text { Chl a } \\
<5 \mu \mathrm{m} \\
-\quad(\mu\end{array}$ & $\begin{array}{l}\text { Chla } \\
\text { Total } \\
\mathrm{l}^{-1} \mathrm{~J}-\end{array}$ & & \\
\hline $\mathrm{H} 1$ & 0.31 & 0.37 & 0.75 & 1.15 & 0.68 & 0.97 \\
\hline E1 & 0.28 & 0.35 & 0.81 & 1.88 & 0.82 & 1.16 \\
\hline W1 & 0.27 & 0.30 & 0.99 & 1.45 & 0.61 & 0.80 \\
\hline N1 & 0.41 & 0.51 & 0.48 & 0.67 & 0.87 & 1.12 \\
\hline $\mathrm{H} 2$ & 0.19 & 0.24 & 0.94 & 1.11 & 0.73 & 1.13 \\
\hline E2 & 0.37 & 0.43 & 0.60 & 1.29 & 0.82 & 1.74 \\
\hline W2 & 0.33 & 0.44 & 0.50 & 0.97 & 0.35 & 0.80 \\
\hline N2 & 0.21 & 0.27 & 0.61 & 0.71 & 0.64 & 0.99 \\
\hline H3 & 0.12 & 0.16 & 0.79 & 0.89 & - & - \\
\hline E3 & 0.20 & 0.29 & 1.01 & 1.10 & 0.63 & 0.89 \\
\hline W3 & 0.25 & 0.31 & 0.48 & 0.62 & 0.83 & 1.03 \\
\hline N3 & 0.09 & 0.22 & 0.17 & 0.84 & 0.33 & 0.92 \\
\hline $\mathrm{H} 4$ & 0.44 & 0.58 & 0.04 & 0.05 & 0.86 & 1.24 \\
\hline E4 & 0.54 & 0.63 & 0.45 & 0.54 & 1.11 & 1.49 \\
\hline W4 & 0.33 & 0.40 & 0.19 & 0.32 & 0.82 & 1.06 \\
\hline N4 & 0.24 & 0.27 & 0.72 & 1.01 & 0.62 & 0.88 \\
\hline H5 & 0.22 & 0.28 & 0.21 & 0.39 & 0.84 & 1.16 \\
\hline E5 & 0.37 & 0.45 & 0.26 & 0.48 & 0.67 & 0.95 \\
\hline W5 & 0.22 & 0.29 & 0.36 & 0.41 & 0.77 & 1.18 \\
\hline N5 & 0.34 & 0.54 & 0.42 & 0.59 & 0.54 & 1.22 \\
\hline H6 & 1.00 & 1.29 & 0.04 & 0.06 & 0.70 & 1.03 \\
\hline E6 & 1.03 & 1.50 & 0.18 & 0.22 & 1.00 & 1.36 \\
\hline W6 & 0.58 & 1.06 & 0.10 & 0.13 & 1.37 & 2.16 \\
\hline N6 & 1.27 & 1.64 & 0.14 & 0.17 & 1.14 & 1.80 \\
\hline $\mathrm{H}^{7}$ & 1.63 & 2.17 & 0.12 & 0.15 & 0.96 & 1.82 \\
\hline E7 & 1.41 & 1.93 & 0.12 & 0.14 & 0.99 & 1.41 \\
\hline W7 & 1.65 & 2.43 & 0.04 & 0.11 & 0.88 & 1.86 \\
\hline
\end{tabular}

of the total community, indicating that especially the algae $>5 \mu \mathrm{m}$ attributed to the enhanced nitrate uptake at greater depth near the Dogger Bank.
The average particulate molar $\mathrm{C}: \mathrm{N}$ ratio along the transect was $6.89 \pm 1.26(\mathrm{n}=281)$.

Gross carbon fixation rates were between 30 and $42 \mathrm{mg} \mathrm{C} \mathrm{m} \mathrm{m}^{-3} \mathrm{~d}^{-1}$ at $10 \mathrm{~m}$ with the highest values near the Shetland Islands (Fig. 2a). A carbon fixation maximum near the thermocline (Fig. 2a) never exceeded the fixation rates at the surface. The carbon fixation rate of the $<5 \mu \mathrm{m}$ fraction showed a distribution (Fig. 2b) which was comparable to the activity of the total communities. Along the entire transect (Stns H1 to $\mathrm{H7}$ ), the average carbon fixation rate for the total communities was $1.22 \pm 0.28 \mathrm{~g} \mathrm{C} \mathrm{m}^{-2} \mathrm{~d}^{-1}$ ( $\mathrm{n}=33$ ). On average, the $<5 \mu \mathrm{m}$ fraction contributed $65 \%(0.79 \pm$ $0.18 \mathrm{~g} \mathrm{C} \mathrm{m}^{-2} \mathrm{~d}^{-1}, \mathrm{n}=33$ ) of the total carbon fixation rate.

Relating nitrogen uptake rates and carbon fixation rates to algal biomass yielded estimates of specific algal growth rates along the transect. In general the specific algal growth rate (based on nitrogen uptake and presented as $\mu_{N}$ in Fig. 3) varied amongst the different stations without any significant trend. However, the specific growth rate of the communities at $40 \mathrm{~m}$ were generally lower than the specific growth rate of the communities at $10 \mathrm{~m}$ depth (Fig. 4). The average algal growth rate was $0.39 \pm 0.17 \mathrm{~d}^{-1}(\mathrm{n}=19)$ for the smaller size fraction at $10 \mathrm{~m}$. The larger size fraction had a slightly higher average specific growth rate $\left(0.43 \pm 0.12 d^{-1} ; n=15\right)$. For the sub-surface communities (at $40 \mathrm{~m}$ ), a lower $\mu_{\mathrm{N}}$ was observed: $0.17 \pm 0.09 \mathrm{~d}^{-1}$ ( $n=15$ ) for the $<5 \mu \mathrm{m}$ fraction. At this greater depth, the larger phytoplankton were growing significantly more slowly $(p<0.025)$ than the smaller species: $\mu_{\mathrm{N}}=$ $0.10 \pm 0.06 \mathrm{~d}^{-1}(\mathrm{n}=15)$ for the $>5 \mu \mathrm{m}$ fraction.

The chl a specific carbon uptake rates $\left(\mu_{c}\right)$, which yielded estimates of the specific growth rate (averaged

Table 3. Values for chl $a$, nutrients, nitrogen uptake rates and specific growth rates, averaged for all stations along the transect from the Dogger Bank to the Shetland Islands in August/July 1994, measured at $10 \mathrm{~m}$ and $40 \mathrm{~m}$ depth. Data are presented as mean value \pm standard deviation (number of samples)

\begin{tabular}{|c|c|c|c|}
\hline & $10 \mathrm{~m}$ & $40 \mathrm{~m}$ & Units \\
\hline Chl $a(<5 \mu \mathrm{m})$ & $0.50 \pm 0.33(34)$ & $0.43 \pm 0.29(34)$ & $\mu g l^{-1}$ \\
\hline Chl a (total fraction) & $0.68 \pm 0.47(34)$ & $0.63 \pm 0.42(34)$ & $\mu g l^{-1}$ \\
\hline Ammonium & $0.17 \pm 0.05(27)$ & $1.40 \pm 0.90(34)$ & $\mu \mathrm{M}$ \\
\hline Urea & $0.15 \pm 0.09(26)$ & $0.15 \pm 0.06(34)$ & $\mu \mathrm{M}$ \\
\hline Nitrate & $0.16 \pm 0.13(27)$ & $2.61 \pm 1.79(34)$ & $\mu \mathrm{M}$ \\
\hline Total $N$-uptake rate $(<5 \mu \mathrm{m})$ & $0.23 \pm 0.11(22)$ & $0.10 \pm 0.08(15)$ & $\mathrm{mg} \mathrm{N} \mathrm{m} \mathrm{N}^{-3} \mathrm{~h}^{-1}$ \\
\hline Total N-uptake rate (total fraction) & $0.31 \pm 0.15(24)$ & $0.12 \pm 0.09(17)$ & $\mathrm{mg} \mathrm{N} \mathrm{m} \mathrm{N}^{-3} \mathrm{~h}^{-1}$ \\
\hline$f$-ammonium $(<5 \mu \mathrm{m})$ & $60 \pm 13(22)$ & $74 \pm 15(16)$ & $\%$ of total $N$ uptake by $<5 \mu \mathrm{m}$ fraction \\
\hline$f$-urea $\quad(<5 \mu \mathrm{m})$ & $32 \pm 14(22)$ & $14 \pm 11(16)$ & $\%$ of total $\mathrm{N}$ uptake by $<5 \mu \mathrm{m}$ fraction \\
\hline$f$-nitrate & $8 \pm 4(22)$ & $12 \pm 9(16)$ & $\%$ of total $N$ uptake by $<5 \mu \mathrm{m}$ fraction \\
\hline f-ammonium (total fraction) & $60 \pm 12(24)$ & $67 \pm 15(17)$ & $\%$ of total $N$ uptake by total fraction \\
\hline$f$-urea (total fraction) & $31 \pm 13(24)$ & $16 \pm 11(17)$ & $\%$ of total $N$ uptake by total fraction \\
\hline$f$-nitrate $\quad$ (total fraction) & $9 \pm 5(24)$ & $17 \pm 7(17)$ & $\%$ of total $N$ uptake by total fraction \\
\hline$(<5 \mu \mathrm{m})$ & $0.39 \pm 0.17(19)$ & $0.17 \pm 0.09(15)$ & $\mathrm{d}^{-\mathrm{t}}$ \\
\hline (total fraction) & $0.38+0.16(17)$ & $0.12 \pm 0.11(15)$ & $\mathrm{d}^{-1}$ \\
\hline
\end{tabular}



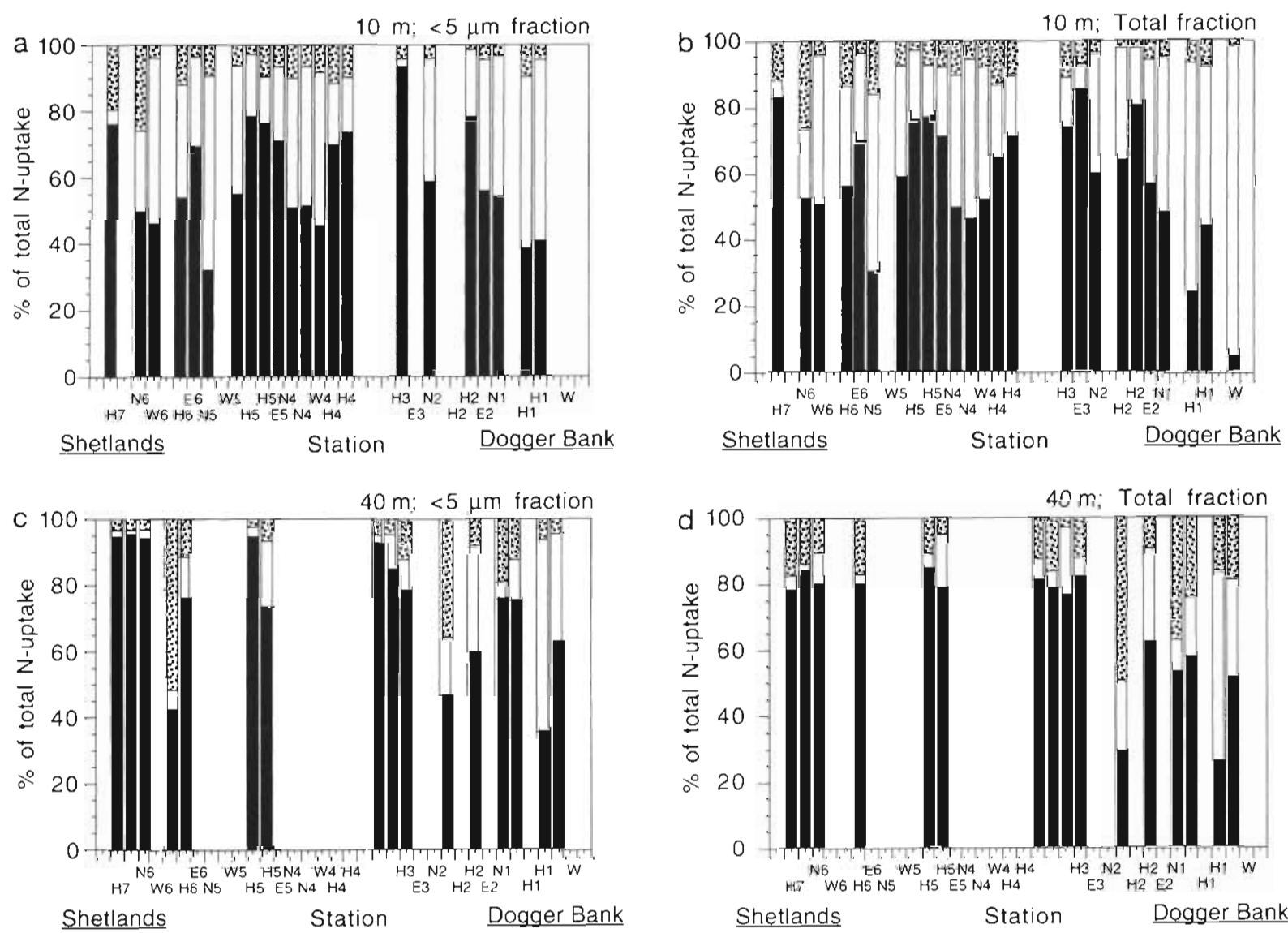

Fig. 1. Relative uptake rates of nitrate (upper, dotted), urea (middle, white), and ammonium (lower, black), calculated as percentage of the total nitrogen uptake rate by the specified fraction, at the different stations for: (a) the $<5 \mu \mathrm{m}$ fraction at $10 \mathrm{~m}$, (b) the total community at $10 \mathrm{~m}$, (c) the $<5 \mu \mathrm{m}$ fraction at $40 \mathrm{~m}$, and (d) the total community at $40 \mathrm{~m}$

over the photic zone), showed an even stronger variation than $\mu_{\mathrm{N}}$ (Fig. 5). A significantly higher $(0.1>\mathrm{p}>$ $0.05)$, specific growth rate $\left(\mu_{C}\right)$ for the total communities was found $\left(0.47 \pm 0.21 \mathrm{~d}^{-1}[\mathrm{n}=32]\right.$ versus $0.41 \pm$ $0.14 \mathrm{~d}^{-1}[\mathrm{n}=33]$ for the $>5 \mu \mathrm{m}$ size fraction]. These calculated specific growth rates, based on inorganic carbon uptake, were in reasonably good agreement with the data calculated from nitrogen uptake.

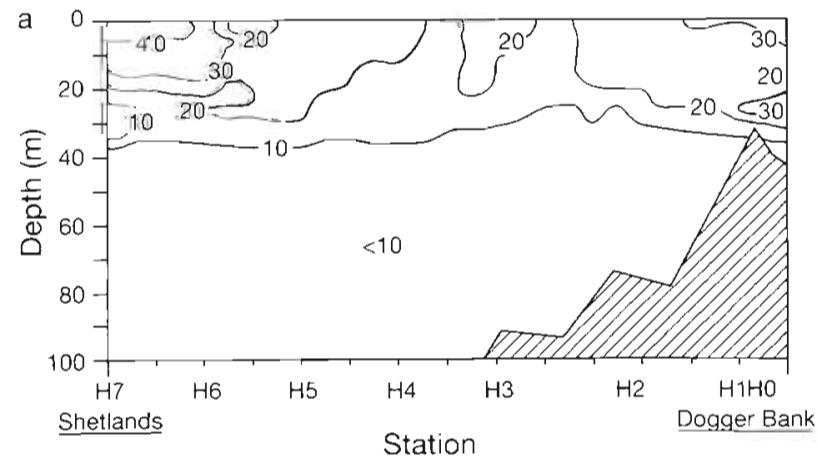

Apparently, the smaller algae grew faster than the larger ones only in the typically light-controlled deeper layers. However, in the nutrient-controlled surface layer the larger species grew as fast as, or even faster than, the smaller species.

Primary production, defined as the daily net biomass production by phytoplankton, was calculated from the specific phytoplankton growth rate (estimated from

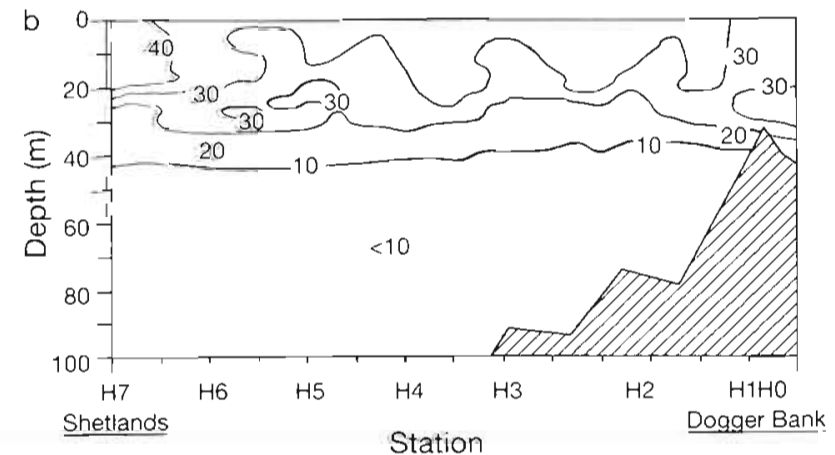

Fig. 2. Carbon fixation rates $\left(\mathrm{mg} \mathrm{C} \mathrm{m}^{-3} \mathrm{~d}^{-1}\right.$ ) by (a) the $<5 \mu \mathrm{m}$ fraction and (b) the total communities along the transect during summer 1994 


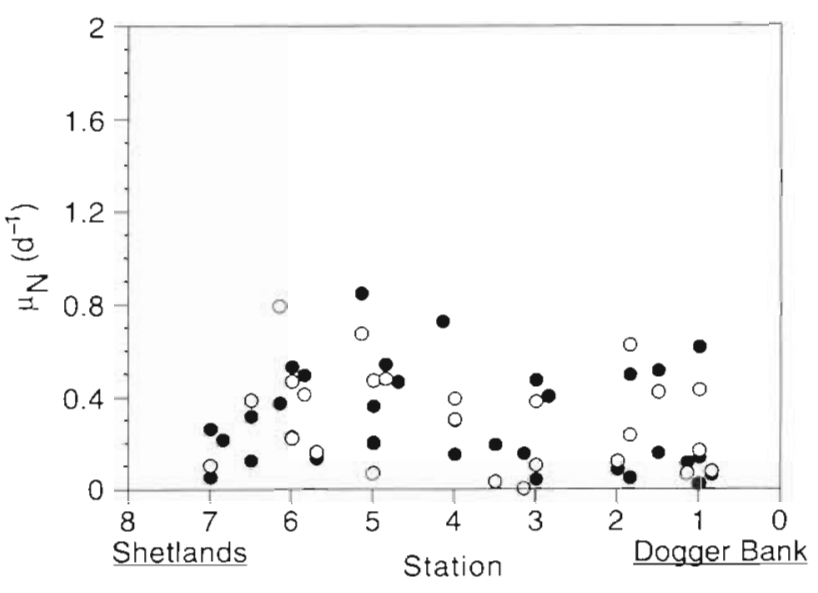

Fig. 3. Specific growth rate of phytoplankton, calculated on the basis of nitrogen uptake $\left(\mu_{N}\right)$, for the algae $<5 \mu \mathrm{m}(\bullet)$ and the total phytoplankton communities (0). Data from $10 \mathrm{~m}$ and $40 \mathrm{~m}$ samples

nitrogen uptake) and the actual biomass of the populations. Along the entire transect, primary production varied up to a factor 8 between the different stations (Fig. 6). Average values for the $<5 \mu \mathrm{m}$ fraction and the total community were $0.37 \pm 0.19 \mathrm{~g} \mathrm{C} \mathrm{m}^{-2} \mathrm{~d}^{-1}(\mathrm{n}=20)$ and $0.50 \pm 0.26 \mathrm{~g} \mathrm{C} \mathrm{m}^{-2} \mathrm{~d}^{-1}(\mathrm{n}=20)$, respectively.

\section{DISCUSSION}

In combination with previous findings along the same transect during spring (Riegman et al. 1998), 3 essentially different environments can be distingu-

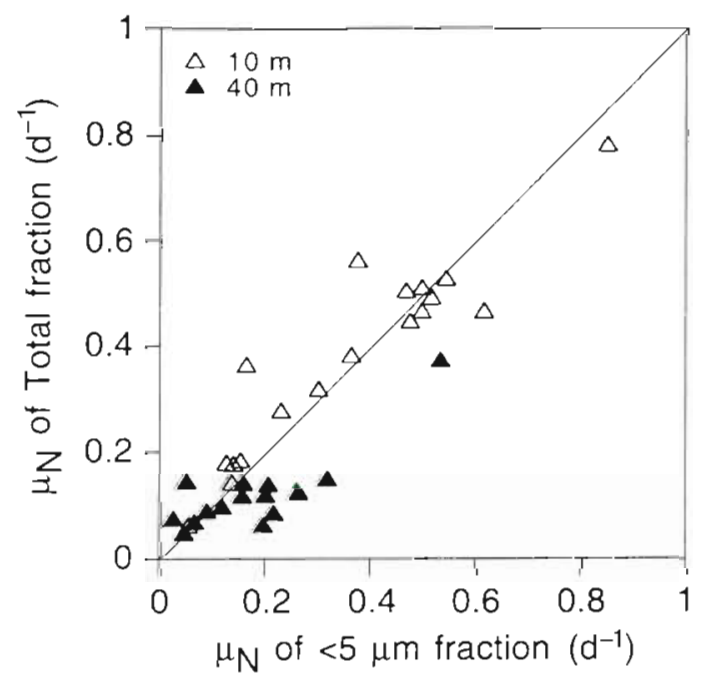

Fig. 4. Relationship between the specific growth rates of the total communities and the specific growth rates of the $<5 \mu \mathrm{m}$ fraction (both estimated from chl a specific nitrogen uptake), collected at $10 \mathrm{~m}(\Delta)$ or $40 \mathrm{~m}(\Delta)$ depth

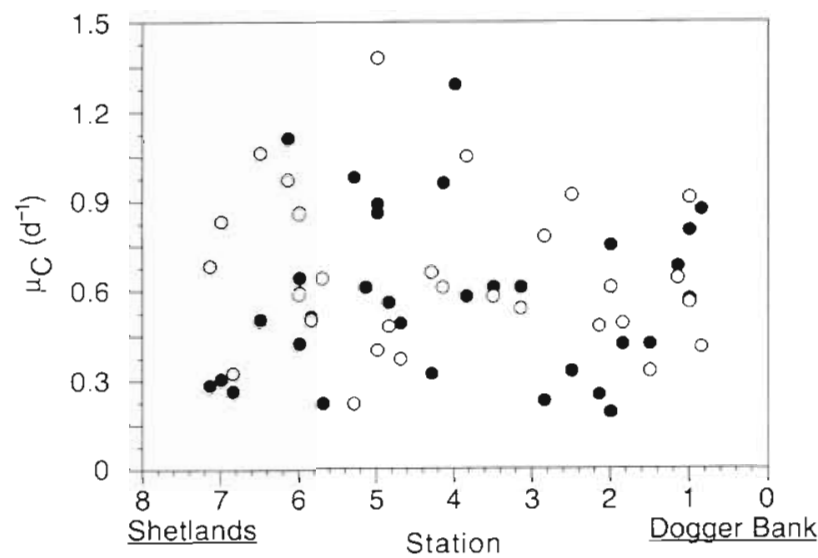

Fig 5. Specific growth rate of phytoplankton, calculated on the basis of inorganic carbon uptake $\left(\mu_{C}\right)$, for the algae $<5 \mu \mathrm{m}$ ( ) and the total phytoplankton communities (O)

ished. First, in spring, the phytoplankton was irradiance controlled, the main nitrogen source was nitrate, and the algae $<5 \mu \mathrm{m}$ grew faster than the larger ones. Second, in summer, at $40 \mathrm{~m}$ depth, major nutrients were in excess and low irradiance levels prevailed. Just below the thermocline the community was irradiance controlled, the main nitrogen source was ammonium, and again the algae $<5 \mu \mathrm{m}$ grew faster than the larger ones. Third, at $10 \mathrm{~m}$ depth during summer stratification, major nutrients were depleted, irradiance in excess (Riegman et al. 1990a), and reduced nitrogen (ammonium + urea) was the main nitrogen source. Here, algae in the small size class grew at a similar rate to the larger ones.

From this comparison it could be concluded that in light-controlled environments smaller algae grow

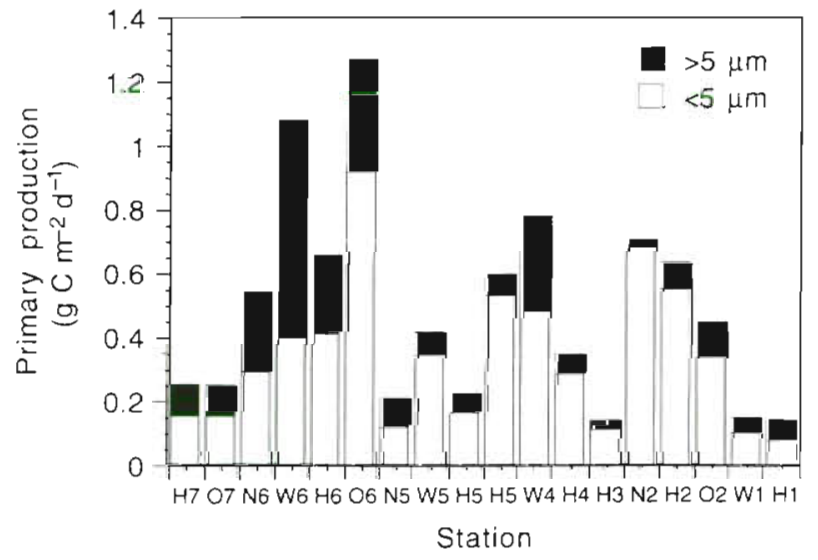

Fig. 6. Primary production, presented cumulatively, of the $>5 \mu \mathrm{m}$ phytoplankton (black) and the $<5 \mu \mathrm{m}$ size fraction (grey), calculated as the product of algal biomass and their specific growth rates estimated from nitrogen uptake, along the transect 
faster than larger ones, irrespective of whether ammonium or nitrate was consumed. This conclusion is in agreement with the theoretical prediction of Raven (1984), who calculated the growth rate of algal cells on the basis of their size-related irradiance harvesting and cell synthesis efficiency. Basically, he concluded that larger cells should be poorer competitors for light than smaller ones, since the ratio between cellular photon absorption and the energy requirement for cell synthesis decreases with cell size. Apparently, the redox status of the consumed nitrogen had no differential effect on the growth rate of algal size classes under light limitation. This is in agreement with former laboratory studies (Thompson et al. 1989, Levasseur et al. 1993) which showed that the use of ammonium rather than nitrate is of little energetic importance in terms of growth rate at low photon flux densities. Despite their higher specific growth rate, the $<5 \mu \mathrm{m}$ algae were not capable of building up biomass to the same extent as the $>5 \mu \mathrm{m}$ species. We observed the same phenomenon during a spring bloom in Dutch coastal waters, where the biomass of the smallest and fastest growing algal size fraction was kept under microzooplankton grazing control, thereby gradually channelling the nutrients into the poorly grazed size fraction of larger algae (Riegman et al. 1993).

During summer stratification, ammonium, nitrate and urea were present in equal, and low, amounts (Table 3) in the upper layers. Yet, there was a preference for nitrogen in the reduced form, as indicated by the contribution of ammonium and urea, being 60 and $32 \%$, respectively, of the total nitrogen uptake for the $<5 \mu \mathrm{m}$ fraction and 60 and $31 \%$, respectively, for the total community. According to experimental research, large algae can accumulate nitrogen just as fast as smaller cells under nitrogen limitation, if reduced nitrogen is the major nitrogen source (Stolte et al. 1994). Our field data consolidate these findings: the specific growth rate of the $<5 \mu \mathrm{m}$ fraction $\left(0.39 \mathrm{~d}^{-1}\right)$ was comparable to the specific growth rate of the $>5 \mu \mathrm{m}$ fraction $\left(0.38 \mathrm{~d}^{-1}\right)$. However, it should be kept in mind that there is another possible explanation for the observation of the absence of size differential growth rates. The $>5 \mu \mathrm{m}$ fraction may have been dominated by colonies or chains of small cells expressing the same physiological activities as cells in the $<5 \mu \mathrm{m}$ fraction. Unfortunately, we have no microscopical information to exclude this alternative explanation.

It has been argued that the advantage of larger algal species having a higher storage capacity for nitrate in their vacuole will only result in higher growth rates of larger species than smaller ones when nitrate is the major nitrogen source under fluctuating, nitrogen limiting conditions (Stolte \& Riegman 1995). This situation may have prevailed at the stations near the Shetland
Islands (N6 to W7), where enhanced nitrate levels were present in the photic zone and the highest $f$-ratios for nitrate $(26.3$ to $27.1 \%$ ) in the surface layers were found. Here, the specific growth rate of the algae $>5 \mu \mathrm{m}$ was much higher $\left(0.43 \mathrm{~d}^{-1}\right)$ than that of the $<5 \mu \mathrm{m}$ fraction $\left(0.10 \mathrm{~d}^{-1}\right)$.

The algal biomass distribution (estimated from chl a) between the different size fractions did not reflect the differences in specific growth rates. This indicates that loss factors may have been more decisive for the observed size distribution in biomass than growth properties. During spring, reduced losses due to sedimentation and grazing in a well-mixed water column with a low abundance of mesozooplankton (Fransz et al. 1998) may have resulted in the dominance of larger algal species (Kuipers \& Witte 1998, Riegman et al. 1998). Picoalgae biomass is usually fairly constant over the entire range of total chl a in water masses (Raimbault et al. 1988, Søndergaard et al. 1991), increasing only occasionally above $1 \mathrm{\mu g} \mathrm{l}^{-1}$ (Søndergaard et al. 1991). During summer, a stratified water column may have facilitated a shift in biomass towards smaller algae, due to their lower sedimentation losses in this type of environment compared to larger algae (Kiørboe et al. 1990, Kiørboe 1993). Also, mesozooplankton biomass was much higher during summer as compared to spring, which may have facilitated additional grazing losses of the larger algae (Banse 1994).

There are several indications that the difference between large and small phytoplankton in taking up new nitrogen is less clear than previously thought. Apart from differences between size classes in their acclimation of nitrogen uptake, being dependent on the controlling factor as argued above, biomass distribution, being affected by loss factors, will have an additional impact on size fractionated nitrogen uptake. For example, if the spring bloom is largely dominated by large phytoplankton, most of the new production (i.e. nitrate uptake) will be performed by these algae, even if they grow somewhat more slowly than the smaller species. Vice versa, an autumn bloom, which follows a period of stratification and a more than $80 \%$ predominance of small species, may show the highest new production in the smallest size class, even if the larger algae, being much lower in abundance, have a higher affinity for nitrate (as observed by e.g. Dauchez et al. 1996).

The nitrate $f$-ratio of the total communities was on average $10 \%$ higher than the $f$-ratio of the $<5 \mu \mathrm{m}$ fraction. This may very well have been due to bacterial nitrogen uptake with a preference for reduced nitrogen, which would be most pronounced in the smallest. size fraction (Harrison \& Wood 1988). In the surface layers with equal amounts of ammonium, nitrate, and urea, ammonium was taken up twice as fast as urea. This is in agreement with findings in the Barents Sea 
(Kristiansen et al. 1994), in Antarctica (Cochlan et al. 1993), in the Skagerrak (Karlson et al. 1996) and earlier measurements (Eppley \& Peterson 1979). However, it should be mentioned that the contribution of urea (amongst others produced by heterotrophic microflagellates) (Andersson et al. 1985) to the total nitrogen uptake can vary from 3\% to more than $91 \%$ (McCarthy 1972, McCarthy et al. 1977, Bury et al. 1995, Takahashi et al. 1995).

New production was 9 and $1.7 \%$ in the surface and deeper layers, respectively. In a comparable study on the thermally stratified central North Sea in 1987. Owens et al. (1990) also identified ammonium as the major nitrogen source assimilated, with a nitrate $f$-ratio of $25 \%$ in the surface waters. Urea uptake was not included in this study. Non-inclusion of urea uptake would have led to a $44 \%$ overestimation of the nitrate $f$-ratio according to our data, which is comparable to the expected $42 \%$ as reported for oceanic waters (Wafar et al. 1995). Correction of the data from Owens et al. (1990) for urea uptake yields a $f$-ratio for nitrate of $17 \%$, which is somewhat higher than we measured $7 \mathrm{yr}$ later. In general, new production near the thermocline was twice that near the surface. Net primary production, calculated on the basis of nitrogen uptake, was $42 \%$ of the gross ${ }^{14} \mathrm{C}$ fixation rates, and showed a considerable variation amongst the different stations. This variation indicates that carbon fixation is quite uncoupled from algal growth in nutrient-controlled systems.

Summarizing, it can be stated that size-partitioning of algal growth rate appears to depend on the character of the growth rate limiting factor. Smaller algae grew faster than larger ones in light-controlled environments, regardless of the nitrogen source which was consumed.

In typically nitrogen-controlled surface layers, no size partitioning of algal growth rate was present when ammonium was the major nitrogen source. At some stations, where nitrogen limitation co-occurred with enhanced nitrate consumption, larger algae did grow faster than smaller ones.

The algal biomass in different size classes was not related to the estimated growth rates of these different categories. Apparently, larger algae do not dominate during summer in the surface layers of the stratified central North Sea, since mesozooplankton densities are high compared to spring and vertical mixing in the photic zone is low. In the lower part of the photic zone, the larger algae do not dominate since they grow much slower than the smaller species due to light limitation.

Acknowledgements. We thank the officers and crew of the RV 'Zirfaea' for their excellent support during the cruise, and Willem Stolte, Bouwe Kuipers, and Gerhard J. Herndl. for their critical comments on the manuscript. Many thanks go to
Rikus Kloosterhuis for assistance with the ${ }^{15} \mathrm{~N}$ analysis, Karel Bakker for macronutrient analyses, and Harry Witte and Simone Kip for chl a analyses. We also thank 3 anonymous referees for their valuable comments.

\section{LITERATURE CITED}

Andersson A, Lee C, Azam F, Hagström A (1985) Release of amino acids and inorganic nutrients by heterotrophic marine microflagellates. Mar Ecol Prog Ser 23:99-106

Banse K (1994) Grazing and zooplankton production as key controls of phytoplankton production in the open ocean. Oceanography $7(1): 13-20$

Blasco D, Packard TT, Garfield PC (1982) Size dependence of growth rate, respiratory electron transport system activity, and chemical composition in marine diatoms in the laboratory. J Phycol 18:58-63

Bury SJ, Owens NJP, Preston T $(1995){ }^{13} \mathrm{C}$ and ${ }^{15} \mathrm{~N}$ uptake by phytoplankton in the marginal ice zone of the Bellingshausen Sea. Deep-Sea Res II 42(4-5):1225-1252

Chisholm S (1992) Phytoplankton size. In: Falkowski PG, Woodhead AD (eds) Primary productivity and biogeochemical cycles in the sea. Plenum Press, New York, p 213-237

Cochlan W, Harrison PA, Denman KL (1991) Diel periodicity of nitrogen uptake by marine phytoplankton in nitraterich environments. Limnol Oceanogr 36(8): 1689-1700

Cochlan WP, Martinez J, Holm-Hansen O (1993) RACER: utilization of nitrate, ammonium, and urea during austrial winter in Gerlache Strait, Antarctica. Antarct J US 28(5): $169-172$

Colijn F (1983) Primary production in the Ems-Dollard estuary. Thesis, Univ Amsterdam

Dauchez S, Legendre L, Fortier L, Levasseur M (1996) Nitrate uptake by size-fractionated phytoplankton on the Scotian Shelf (Northwest Atlantic): spatial and temporal variability. J Plankton Res 18(4):577-595

Dugdale RC, Goering JJ (1967) Uptake of new and regenerated forms of nitrogen in primary productivity. Limnol Oceanogr 1.2:196-206

Eppley RW (1972) Temperature and phytoplankton growth in the sea. Fish Bull US 70:1063-1085

Eppley RW, Peterson BJ (1979) Particulate organic matter flux and planktonic new production in the deep ocean. Nature 282:677-680

Fransz HG, Gonzalez SR, Steeneken SF (1998) Metazoan plankton and the structure of the plankton community in the stratified North Sea. Mar Ecol Prog Ser (in press)

Gallegos CL, Vant WN, Safi KA (1996) Microzooplankton grazing of phytoplankton in Manukau Harbour, New Zealand. N Z J Mar Freshwat Res 30:423-434

Gieskes WWC, Kraay GW (1984) Phytoplankton, its pigments, and primary production at a central North Sea station in May, July, and September 1981 Neth J Sea Res 18(1/2): $51-70$

Glibert PM, Garside C (1992) Diel variability in nitrogenous nutrient uptake by phytoplankton in the Chesapeake Bay plume. J Plankton Res 14(2):271-288

Grasshoff K (1967) Methods of seawater analysis. VerlagChemie, Weinheim

Grover JP (1989) Phosphorus-dependent growth kinetics of 11 species of freshwater algae. Limnol Oceanogr 34(2): $341-348$

Harrison WG. Wood LJE (1988) Inorganic nitrogen uptake by marine picoplankton: evidence for size-partitioning. Limnol Oceanogr 33:4.68-475 
Helder W, de Vries RTP (1979) An automatic phenol-hypochlorite method for the determination of ammonia in seaand brackish waters. Neth J Sea Res 13(1):154-160

Holm-Hansen O, Lorenzen CL, Holmes RW, Strickland JDH (1965) Fluorometric determination of chlorophyll. $J$ Cons Perm Int Explor Mer 30:3-15

Kamiyama $\mathrm{T}$ (1994) The impact of grazing by microzooplankton in northern Hiroshima Bay, the Seto Inland Sea, Japan. Mar Biol 119(1):77-88

Karlson B, Edler L, Granéli W, Sahlsten E, Kuylenstierna M (1996) Subsurface chlorophyll maxima in the Skagerakprocesses and plankton community structure. J Sea Res $35(1-3): 139-158$

Kiorboe T (1993) Turbulence, phytoplankton cell size, and the structure of pelagic food webs. Adv Mar Biol 29:1-72

Kiørboe T, Kaas H, Kruse B, Møhlenberg F, Tiselius P, Ertebjerg $G$ (1990) The structure of the pelagic food web in relation to water column structure in the Skagerrak. Mar Ecol Prog Ser 59:19-32

Kristiansen S, Farbrot T, Wheeler PA (1994) Nitrogen cycling in the Barents Sea-seasonal dynamics of new and regenerated production in the marginal ice zone. Limnol Oceanogr 39(7):1630-1642

Kuipers BR. Witte HJ (1998) Grazing impact of microzooplankton on different size classes of algae in the North Sea in early spring and late summer. Mar Ecol Prog Ser (in press)

Landry MR, Constantinou J, Kirshtein J (1995) Microzooplankton grazing in the Central Equatorial Pacific during February and August, 1992. Deep-Sea Res 42(2-3):657-671

Levasseur M, Thompson PA, Harrison, PJ (1993) Physiological acclimation of marine phytoplankton to different nitrogen sources. J Phycol 29:587-595

Lüning K (1981) Light. Bot Monogr 17:326-355

MacManus GB, Ederington-Cantrell MC (1992) Phytoplankton pigments and growth rates, and microzooplankton grazing in a large temperate estuary. Mar Ecol Prog Ser $87(1-2): 77-85$

Margalef R (1978) Life-forms of phytoplankton as survival alternatives in an unstable environment. Oceanol Acta 1. 493-509

McCarthy JJ (1972) The uptake of urea by populations of marine phytoplankton. Limnol Oceanogr 17:738-748

McCarthy JJ, Taylor WR, Taft JL (1977) Nitrogenous nutrition of the plankton in the Chesapeake Bay. 1. Nutrient availability and phytoplankton preferences. Limnol Oceanogr 22:996-1011

Mortain-Bertrand A, Descolas-Gros C, Jupin H (1988) Pathway of dark inorganic carbon fixation in two species of diatoms: influence of light regime and regulator factors on diel variations. J Plankton Res 10:199-217

Nielsen TG, Løkegaard B, Richardson K, Pederson FB, Hansen L (1993) Structure of plankton communities in the Dogger Bank area (North Sea) during a stratification situation. Mar Ecol Prog Ser 95:115-131

Owens NJP, Woodward EMS, Aiken J, Bellan IE, Rees AP (1990) Primary production and nitrogen assimilation in the North Sea during July 1987 Neth J Sea Res 25(1/2): 143-154

Paranjape MA (1990) Microzooplankton herbivory on the Grand Bank (Newfoundland, Canada): a seasonal study. Mar Biol 107(2) 321-328

Platt T, Gallegos CL, Harrison WG (1980) Photoinhibition of photosynthesis in natural assemblages of marine phytoplankton. J Mar Res 38:687-701

Probyn TA (1985) Nitrogen uptake by size-fractionated phytoplankton populations in the southern Benguela upwelling system. Mar Ecol Prog Ser 22:249-258

Probyn TA, Painting SJ (1985) Nitrogen uptake by sizefractionated phytoplankton populations in Antarctic surface waters. Limnol Oceanogr 30(6):1327-1332

Probyn TA, Waldron HN, James AG (1990) Size-fractionated measurements of nitrogen uptake in aged upwelled waters: implications for pelagic food webs. Limnol Oceanogr 35:202-210

Raimbault P, Rodier M and Taupier-Letage I (1988) Vertical size distribution of phytoplankton in the western Mediterranean Sea during early summer. Mar Ecol Prog Ser 45:153-158

Raven JA (1984) Energetics and transport in aquatic plants. MBL lectures in biology. 4. Alan R Liss, New York

Riegman R (1985) Phosphate-phytoplankton interactions. Thesis, Univ Amsterdam

Riegman R, Colijn F (1991) Evaluation of measurements and calculation of primary production in the Dogger Bank area (North Sea) in summer 1988. Mar Ecol Prog Ser 69: $125-132$

Riegman R, Malschaert H, Colijn F (1990a) Primary production of phytoplankton at a frontal zone located at the northern slope of the Dogger Bank (North Sea). Mar Biol 105:329-336

Riegman R, Colijn F, Malschaert JFP, Kloosterhuis HT, Cadée GC (1990b) Assessment of growth rate limiting nutrients in the North Sea by the use of nutrient-uptake kinetics. Neth J Sea Res 26(1):53-60

Riegman R, Kuipers BR, Noordeloos AAM, Witte HJ (1993) Size-differential control of phytoplankton and the structure of plankton communities. Neth J Sea Res 31(3): $255-265$

Riegman R, de Boer M, de Senerpont Domis L (1996) Growth of harmful marine algae in multispecies cultures. J Plankton Res 18(10): 1851-1866

Riegman R, Flameling IA, Noordeloos AAM (1998) Size differential uptake of ammonium, nitrate and urea and phytoplankton growth in the North Sea during spring 1994. Mar Ecol Prog Ser 173:85-94

Søndergaard M, Jensen LM, Artebjerg G (1991) Picoalgae in Danish coastal waters during summer stratification. Mar Ecol Prog Ser 79:139-149

Stolte W, McCollin T, Noordeloos AAM, Riegman R (1994) Effect of nitrogen source on the size distribution within marine phytoplankton populations. J Exp Mar Biol Ecol 184:83-97

Stolte W. Riegman R (1995) The effect of phytoplankton cell size on transient state nitrate and ammonium uptake kinetics. Microbiology 141:1221-1229

Stolte W, Riegman R (1996) The Relative Preference Index (RPI) for phytoplankton nitrogen use is only weakly related to physiological preference. J Plankton Res 18 : $1041-1045$

Strickland JD, Parsons TR (1972) A practical handbok of sea water analysis. Bull Fish Res Bd Can 167:1-311

Strom SL, Welschmeyer NA (1991) Pigment-specific rates of phytoplankton growth and microzooplankton grazing in the open subarctic Pacific Ocean. Limnol Oceanogr 36(1): $50-63$

Takahashi T, Hama T, Matsunaga K, Handa N (1995) Nitrogenous nutrient uptake by phytoplankton and ammonium regeneration by microbial assemblage in Lake Biwa. J Plankton Res 17(5):1027-1037

Thingstad TF, Sakshaug E (1990) Control of phytoplankton growth in nutrient recycling ecosystems. Theory and terminology. Mar Ecol Prog Ser 63:261-272

Thompson PA, Levasseur ME, Harrison PJ (1989) Light- 
limited growth on ammonium vs nitrate: what is the advantage for marine phytoplankton? Limnol Oceanogr $34(6): 1014-1024$

Timmermans KR, Gledhill M, Nolting RF, Veldhuis MJW, de Baar HJW, van den Berg CMG (1998) Responses of marine phytoplankton in. iron enrichment experiments in the northern North Sea and northeast Atlantic Ocean. Mar Chem 61:229-242

Verity PG (1986) Grazing of phototrophic nanoplankton by microzooplankton in Narrangansett Bay. Mar Ecol Prog Ser 29:105-115

Vermij SG (1987) Analyses of algal growth in Lake Maars-

Editorial responsibility: Otto Kinne (Editor),

Oldendorf/Luhe, Germany seveen by means of mathematical modelling. Thesis, Univ Amsterdam.

Wafar MVM, Le Corre P. 'Helguen SL (1995) $f$-ratios calculated with and without urea uptake in nitrogen uptake by phytoplankton. Deep-Sed Res 42(9):1669-1674

Wal P van der, Kempers RS, Veldhuis MJW (1995) Production and downward flux of organic matter and calcite in a North Sea bloom of the coccolithophore Emiliania huxleyi. Mar Ecol Prog Ser 126:247-265

Woodward EMS, Owens NJP (1990) Nutrient depletion studies in offshore North Sea areas. Neth J Sea Res 25(1/2): $57-63$

Submitted: February 23, 1998; Accepted: July 31, 1998 Proofs received from author(s): October 26, 1998 